\title{
Review \\ The Underestimated Role of Platelets in Severe Infection a Narrative Review
}

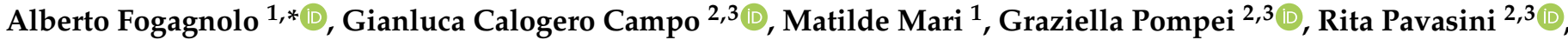 \\ Carlo Alberto Volta ${ }^{1}$ (i) and Savino Spadaro ${ }^{1}$ (D)
}

1 Intensive Care Unit, Department of Translational Medicine and for Romagna, Azienda Ospedaliera Universitaria di Ferrara, University of Ferrara, 44121 Ferrara, Italy; matilde.mari@student.unife.it (M.M.); vlc@unife.it (C.A.V.); savinospadaro@gmail.com (S.S.)

2 Cardiovascular Institute, Azienda Ospedaliero-Universitaria di Ferrara, 44124 Cona, Italy; cmpglc@unife.it (G.C.C.); graziella.pompei@outlook.it (G.P.); pvsrti@unife.it (R.P.)

3 Maria Cecilia Hospital, GVM Care and Research, 48032 Cotignola, Italy

* Correspondence: alberto.fogagnolo@gmail.com

check for updates

Citation: Fogagnolo, A.; Campo, G.C.; Mari, M.; Pompei, G.; Pavasini, R.; Volta, C.A.; Spadaro, S. The Underestimated Role of Platelets in Severe Infection a Narrative Review. Cells 2022, 11, 424. https://doi.org/ $10.3390 /$ cells11030424

Academic Editor: Francisco Rivero

Received: 6 December 2021

Accepted: 23 January 2022

Published: 26 January 2022

Publisher's Note: MDPI stays neutral with regard to jurisdictional claims in published maps and institutional affiliations.

Copyright: (C) 2022 by the authors. Licensee MDPI, Basel, Switzerland. This article is an open access article distributed under the terms and conditions of the Creative Commons Attribution (CC BY) license (https:// creativecommons.org/licenses/by/ $4.0 /)$.

\begin{abstract}
Beyond their role in hemostasis, platelets have emerged as key contributors in the immune response; accordingly, the occurrence of thrombocytopenia during sepsis/septic shock is a wellknown risk factor of mortality and a marker of disease severity. Recently, some studies elucidated that the response of platelets to infections goes beyond a simple fall in platelets count; indeed, sepsis-induced thrombocytopenia can be associated with—or even anticipated by-several changes, including an altered morphological pattern, receptor expression and aggregation. Of note, alterations in platelet function and morphology can occur even with a normal platelet count and can modify, depending on the nature of the pathogen, the pattern of host response and the severity of the infection. The purpose of this review is to give an overview on the pathophysiological interaction between platelets and pathogens, as well as the clinical consequences of platelet dysregulation. Furthermore, we try to clarify how understanding the nature of platelet dysregulation may help to optimize the therapeutic approach.
\end{abstract}

Keywords: platelet; platelet activation; infection; critical care

\section{Platelets Interactions with Bacteria}

The cardiovascular system is usually a sterile environment; however, upon entry to the circulation, bacteria can interact with several cells leading to several complications including bacteremia, sepsis, infective endocarditis, disseminated intravascular coagulation and immune thrombocytopenia purpura. In all these conditions, a common feature is an abnormal platelet function caused by an interaction with the bacteria.

Although the main role of platelets is hemostasis, recently more attention has been focused on the role of platelets in the host response to infection [1-5]. However, under certain circumstances, the platelet response to infection may be a significant part of the problem.

Inflammation and thrombosis both contribute to reducing the spread of pathogens, and platelets migrate to the site of infection and detect pathogens, along with neutrophils [6]; in this manner, platelets migration prevents the dissemination of bacteria already located in the intravascular compartment. In addition to this, platelets use their protrusions at vascular microbreaches to prevent the invasion of extravascular bacteria [7]. This complex defense system contains bacterial spreading and promotes the elimination of bacteria from the circulation by sequestration in the hepatic and pulmonary vasculature. The complement system, which is involved in innate and acquired immune responses to different infections, is the fulcrum of the interplay between inflammation and thrombosis [6]. Some studies identified a shuttling mechanism in the spleen involving complement and platelet and 
concerning endovascular bacteria which allows to balance rapid clearance of pathogens with the induction of adaptive immune responses [8].

However, even if platelet response to infection is a crucial step in immune response, under certain circumstances it may be a significant part of the problem.

Bacteria can interact with platelets using different mechanisms; they may secrete products (as toxins) that bind to the platelet-causing activation independently of bacterial attachment $[9,10]$ or may bind to platelets. The binding to platelets can be either a direct interaction or an indirect interaction. A direct interaction (Figure 1A) occurs when a bacterial adhesin binds directly to a platelet receptor [11,12]. An indirect interaction (Figure 1B) occurs when a bacterial adhesin binds to a plasma protein (or other soluble elements of the immune system such as immunoglobulins and complement proteins) which bridge the bacteria to a specific receptor on the platelet surface [11-15]. See Table $1[16,17]$.

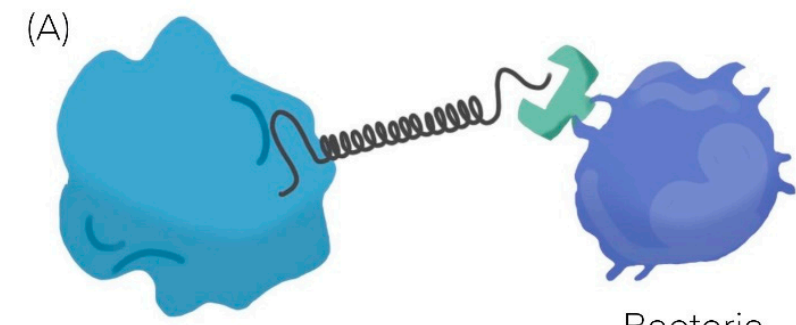

Platelet

Bacteria

(B)

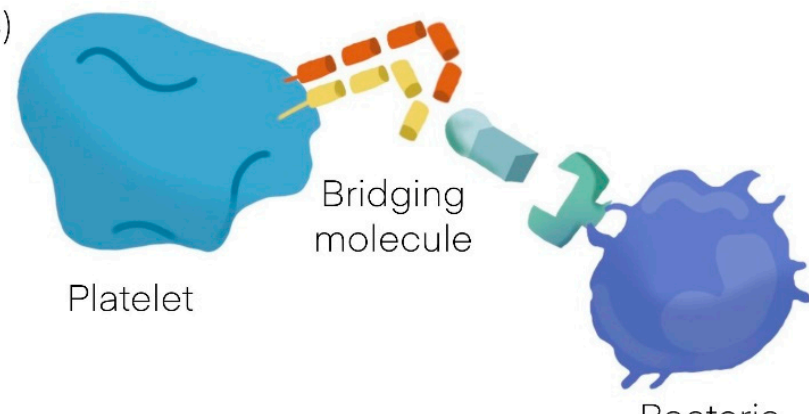

Figure 1. General mechanisms observed in platelet bacterial interaction. (A) Direct interaction. (B) Indirect interaction.

Bacteria can either promote platelet adhesion or can induce platelet aggregation. Platelet adhesion to bacteria is a measure of the strength of the interaction, whereas platelet aggregation is an indication of the quality of the interaction; in contrast to typical platelet aggregation induced by physiological agonists such as adenosine diphosphate (ADP), collagen or thrombin, bacteria induce an all or nothing response. In other words, there is a threshold concentration of bacteria, above which there is maximum aggregation and below which there is no aggregation at all $[16,17]$. Another specific feature of platelet aggregation induced by bacteria is "lag time," which is a distinct pause in time before aggregation takes place. When a soluble agonist such as ADP is added to a suspension of platelets, the aggregation response occurs within a few seconds; otherwise, when bacteria are added to a platelet suspension, there is a concentration-dependent delay in the aggregation response [18]. Depending on bacteria, platelet aggregation may be preceded by a short lag time of around $2-5 \mathrm{~min}[11,19]$ or by a long lag time of about $12-18 \mathrm{~min}[13,20]$. A short lag time usually indicates a direct interaction between the bacteria and the platelet, whereas a long lag time generally indicates an indirect interaction. The length of time relates to how long it takes for the bacteria to bind the bridging molecule and cross-react with the reciprocal receptor on the platelet [16].

The activation of platelets by bacteria can lead to different specific problems. If activation occurs in a localized manner, it can lead to thrombus formation; instead, a more 
systemic activation can lead to platelet consumption. Finally, activated platelets secrete many cytokines and other mediators that can trigger pathological processes. Infective endocarditis (typically due to Staph. aureus or an oral Streptococcus), in which a bacteriaplatelet thrombus develops on the valve, is a typical example of a thrombotic complication of bacterial infection and can either lead to valve failure or the formation of a septic embolus [21]. During septicemia, platelet activation by systemic bacterial infection may lead to thrombocytopenia and bleeding complications due to platelet sequestration [22,23]; and this outcome relates to the entity of thrombocytopenia [24,25].

When activated, platelets secrete their granule contents, which contain at least 300 different proteins including cytokines and vascular activating factors [26,27]. These cytokines play a key role in the pathogenesis of atherosclerosis [26,28-31] and may also explain the association between infection and cardiovascular disease. As well as causing thrombocytopenia, sepsis also leads to shock due to endothelial inflammation and subsequent vascular leakage. Activated platelets play a key role in mediating endothelial damage [23,32,33].

Significant advances have been made in recent years in identifying the molecular mechanisms leading to platelet activation upon binding several bacterial species. Due to the rapid global emergence of multiple resistant strains of bacteria, it is critical that we identify novel drug targets that prevent unwanted platelet activation at the sites of injury in the vasculature. Given that different species of bacteria interact with platelets using various mechanisms, a correct interpretation of this phenomenon is crucial to develop future targeted therapies.

Table 1. Bacterial-platelet interaction can vary depending on etiologic agent.

\begin{tabular}{ccc}
\hline Platelet-Bacteria Interactions & & \\
\hline Direct adhesion & Indirect adhesion & \\
\hline Short lag & Sridging protein \\
S. sanguinis [11] & Fibrinogen \\
S. aureus [12-14] & H. pylori [19] & $\begin{array}{c}\text { Fibronectin } \\
\text { VWF }\end{array}$ \\
& & Direct adhesion \\
Long lag & & \\
S. gordonii [20] & & \\
S. sanguinis [11] & & \\
Non aggregating & H.pylori [19] & \\
S. gordonii [20] & & \\
\hline
\end{tabular}

\section{Platelets Interactions with Viruses}

The relationship between activated platelets and immune response is maintained even when the infectious microorganisms are viruses [34-37]. Viral infection of cells begins with virus binding to a surface receptor that mediates its internalization, and platelets express various pattern recognition receptors $(P R R)$ able to mediate binding and entry of various viruses [36,38-40]. The immune response against viruses is supported by consequent platelet activation and manifests itself through different mechanisms, such as the release of chemokines that promote endothelial signaling and leukocyte migration or by physically interacting with leukocytes [41-43]. Moreover, while traditional platelet activation by Gprotein-coupled receptors is usually rapid, platelet $P R R$ activation in responses to infections and immune stimuli can be delayed and sustained, persisting hours after initial aggregation and secretion [34-44].

Resultant virus-mediated thrombocytopenia is generally multifactorial; viruses use different strategies to decrease the levels of circulating platelets, either by decreasing platelet production or increasing platelet destruction. Platelets are produced in the bone marrow by megakaryocytes, and viruses can interfere with platelet production at various steps of development [36]. Some viruses, such as simian immunodeficiency virus (SIV) and human herpes virus, can influence the cytokine profile of the host, resulting in altered 
thrombopoietin (TPO) production in the liver [45-47]. Some others, including hepatitis C virus (HCV), also directly interfere with TPO production by destruction of liver tissue [48]. Moreover, human immunodeficiency virus (HIV), cytomegalovirus (CMV) and HCV replicate in megakaryocytes modulating their proliferation and function [49-52]. Nevertheless, thrombocytopenia induced by decreased platelet production is observed at later stages of infection; otherwise, rapidly induced thrombocytopenia during viral infections is mediated via enhanced platelet destruction. The most rapid way of platelet destruction occurs via direct interaction between platelets and viruses through a variety of receptors and it is mainly mediated by surface lectins, integrins and TLR $[52,53]$. Rotavirus utilizes the collagen receptor GPIa/II $a$ to bind to platelets $[54,55]$, while hantavirus and adenoviruses interact with platelets via the fibrinogen receptor GPIIb/IIIa, the most abundant platelet integrin. [56] The Epstein-Barr virus' (EBV) interaction with platelets occurs via complement receptor 2 (CR2) [57]; HIV and dengue virus activate platelets by binding to lectin receptors and a cell-specific intercellular adhesion molecule [58]. These direct interactions often result in platelet activation and adhesion of activated platelets to leukocytes. Platelet binding to neutrophils leads to phagocytosis of platelets and platelet activation itself stimulates platelet clearance in the liver and spleen $[59,60]$. However, platelets are not only activated by direct interactions with viruses. Host defense mechanisms in response to viral infections can also lead to platelet activation and decreases platelet life span [61]. Moreover, the B-lymphocyte production of antibodies against some viruses also interferes with platelet survival. These antibodies, which usually target surface glycoproteins of viruses, shows cross-reactivity with platelet surface integrins such as GPIIb/IIIa. That is called idiopathic thrombocytopenic purpura (ITP) or platelet autoantibody-induced thrombocytopenia and it has been described for HCV, HIV, CMV, EBV, hantavirus, varicella zoster virus, herpes viruses, and severe acute respiratory syndrome coronavirus [62]. The interaction between platelets and viruses is crucial even in the pathogenesis of the COVID-19 syndrome. Platelets from COVID-19 patients are more activated, aggregated faster and have increased expression of monocyte tissue factor [39,40]. Functional assays showed that platelets from COVID-19 patients are more responsive, sensitized to release inflammatory cytokines and adhere more efficiently [33]. All things considered, the data suggest that platelets may have the potential to contribute to the thrombo-inflammation in COVID-19 [33].

\section{Cellular Changes in Platelet Structure and Function during Infection}

The interplay between platelets and bacteria or viruses reported above can affect the structure and the function of platelets in several ways. The most known effect of infection is a fall in platelet count, which may show different levels of severity depending on the lowest level of platelet reached. The occurrence of thrombocytopenia has long been recognized as an independent risk factor for worst outcomes during infection, and the degree of thrombocytopenia is used as a marker of the severity during sepsis $[33,63]$. Indeed, the platelet count is included in the Sequential organ failure assessment (SOFA) score [64], the alteration of which is crucial in the diagnosis of sepsis.

Beyond the well-established prognostic finding of thrombocytopenia, there are other less-known platelet characteristics that may be evaluated during infection. Two indices of platelet morphology are easily available in most laboratories and have been shown to be affected by concurrence infections: the platelets distribution width (PDW) and the mean platelet volume (MPV). The PDW is a parameter of platelet heterogeneity, while MPV is a measurement of the average size of platelets. Platelet size is usually between 1.5 and $3 \mu \mathrm{m}$. Large platelets $(3-7 \mu \mathrm{m})$ are called macrothrombocytes, whereas platelets reaching the size of erythrocytes or lymphocytes (larger than 7, up to $20 \mu \mathrm{m}$ ) are designated giant platelets [65]. Healthy subjects usually have less than $5 \%$ of large platelets, but infectioninduced platelet activation is associated with major shape change due to cytoskeletal changes, including filopodial and lamellopodial extensions. These changes affect platelet size and variability and, therefore, MPV and PDW have recently been suggested as markers of platelet activation [66-69]. High PDW and MPV values were associated with 90-day 
mortality in patients with septic shock [62-65]; this was also in experimental animal models of endotoxemia [69]. Notably, studies conducted in non-infected critically ill patients, such as cardiac arrest [70], have not found any prognostic role of these morphological indices; these results suggest a direct role of infection on platelet morphologies, and a recent study confirmed this hypothesis [68]. As a result, both PDW and MPV can be used as a marker of infection severity and they are independent predictors of mortality during infections.

Outside the platelet morphological changes, several other biological changes can be described after platelet activation, which include the expression of different platelet receptors. P-selectin, which can bind leukocytes, is only expressed on the surface of activated platelets [71] and can be responsible for neutrophil-platelet aggregates in the circulating blood [72]. Similarly, CD40-Ligand (CD40L) is expressed on activated platelets, and can trigger an inflammatory response by interacting with CDBoth P-selectin and CD40L can be measured with a bead-based multiplex immunoassay and were associated with worse outcomes both in bacterial [73] and viral infections [74]. Remarkably, experimental studies showed compromised host defense to infection in P-selectin-deficient mice [75]; it appears that only a dysregulated platelet activation can be deleterious in patients with infections.

\section{Main Techniques to Monitor Platelet Function}

The in-vitro evaluation of platelet aggregation is used for the diagnosis of platelet function disorders [76]. There are many methods used to test platelet function; however, these are mainly for research purposes as a result of lack of standardization [77]. Light transmission aggregometry (LTA), developed in 1962 by Born and O'Brien, represents the gold standard for testing platelet function. This technology measures the changes in transmission of light through a sample of platelet-rich plasma (PRP) or platelet suspensions in buffer, which occur when platelets change shape and aggregate upon stimulation. Compared to other methodologies, LTA is far less influenced by platelet count [62]. However, LTA is a time-consuming and technically challenging technique and therefore is mainly used only in specialized laboratories. An alternative system to evaluate platelet aggregation in vitro is impedance aggregometry (IA). It consists of the calculation of the increase in electrical resistance between two electrodes immersed in a diluted sample of whole blood, PRP or platelet suspension, caused by the adhesion of platelets to the electrodes and the subsequent platelet aggregation [76,78]. The IA is calculated by the MultiplateTM analyzer [79], which relies only on platelet aggregometry; this might lead to misdiagnosing dense granule secretion defects. The lumi-aggregometer, a different version of LTA, provides information on platelet secretion in addition to platelet aggregation measures quantifying the ATP secretion with a luciferin/luciferase assay, while aggregation is assessed as in classical LTA. Despite several instruments available to measure lumi-aggregometry, few reports are available in the literature on its performance and validation [77]. To test the behavior of platelets in physiological conditions, it is necessary to add an element of shear in available assays (to mimic shear stress from the blood on the vessel). Between assays available, only the PFA-200 ${ }^{\circledR}$ requires blood to flow over a surface coated with a thrombogenic substrate and the assessment of platelets deposition and thrombus growth by microscopy [77]. Another factor that alters the evaluation of platelet function by traditional assays is low platelet counts. In patients with low platelet counts, the best option consists of flow cytometric assays of platelet activation markers. The use of flow cytometry has some advantages: a smaller volume of blood is needed without platelet-rich plasma preparation [77,80-82]. Several flow cytometry approaches have been successfully used in patients with severe chronic immune thrombocytopenia, showing that impaired platelet function is associated with bleeding, independent of platelet count. The reduced platelet count is related to altered paracrine amplification of platelet responses by ADP release. Therefore, plateletcount-adjusted reference ranges are needed [78,79]. The strengths and the limitations of the main techniques used to monitor platelet function are summoned in Table 2. 
Table 2. Main techniques to monitor platelet function.

\begin{tabular}{|c|c|c|c|}
\hline Technique & Function & Strengths & Pitfalls \\
\hline LTA & $\begin{array}{c}\text { Evaluation of changes in } \\
\text { transmission of light through a } \\
\text { sample of platelet-rich plasma } \\
\text { (PRP) or platelet suspensions in } \\
\text { buffer in response to the addition } \\
\text { of a platelet agonist }\end{array}$ & $\begin{array}{l}\text { Less influenced by platelet count } \\
\text { Available guidelines on how to } \\
\text { interpret LTA results }\end{array}$ & $\begin{array}{c}\text { Time-consuming and technically } \\
\text { challenging technique } \\
\text { High cost of reagents and } \\
\text { consumables }\end{array}$ \\
\hline IA & $\begin{array}{l}\text { Calculation of the increase in } \\
\text { electrical resistance between two } \\
\text { electrodes immersed in a diluted } \\
\text { sample of whole blood, PRP, or } \\
\text { platelet suspension }\end{array}$ & $\begin{array}{l}\text { Shortening of the time window to } \\
\text { surgery following P2Y12 inhibitor } \\
\text { discontinuation }\end{array}$ & $\begin{array}{l}\text { Misdiagnose of dense granule } \\
\text { secretion defects } \\
\text { Inferior to LTA for the detection } \\
\text { and discrimination of mild } \\
\text { platelet function disorders }\end{array}$ \\
\hline $\begin{array}{l}\text { lumi- } \\
\text { aggregometer }\end{array}$ & $\begin{array}{l}\text { Different version of LTA, } \\
\text { quantifying the ATP secretion } \\
\text { with a luciferin/luciferase assay } \\
\text { in parallel with platelet } \\
\text { aggregation measures }\end{array}$ & $\begin{array}{l}\text { Information on platelet secretion } \\
\text { in addition to platelet } \\
\text { aggregation measures }\end{array}$ & $\begin{array}{l}\text { Few reports in the literature on its } \\
\text { performance and validation } \\
\text { Affected by several variables } \\
\text { (concentration of } \\
\text { luciferin/luciferase, agonists and } \\
\text { ATP standard, volume of PPP and } \\
\text { PRP, duration of incubation and } \\
\text { measurement, adjustment of } \\
\text { platelet count of the PRP). }\end{array}$ \\
\hline PFA-200 & $\begin{array}{l}\text { Assessment of platelet deposition } \\
\text { and thrombus growth by } \\
\text { microscopy requiring blood to } \\
\text { flow over a surface coated with a } \\
\text { thrombogenic substrate }\end{array}$ & $\begin{array}{l}\text { Comprehension of the behavior of } \\
\text { platelets under physiological and } \\
\text { pathological flow, as it occurs } \\
\text { within a vessel }\end{array}$ & $\begin{array}{l}\text { Fairly insensitive for the detection } \\
\text { of mild platelet function defects }\end{array}$ \\
\hline Flow cytometry & $\begin{array}{l}\text { Analysis of the expression of } \\
\text { activation markers on } \\
\text { platelets surface }\end{array}$ & $\begin{array}{l}\text { A smaller volume of blood is } \\
\text { needed without platelet-rich } \\
\text { plasma preparation }\end{array}$ & $\begin{array}{c}\text { Further validation and } \\
\text { standardization tests are required } \\
\text { before its application in } \\
\text { diagnostic laboratories }\end{array}$ \\
\hline
\end{tabular}

LTA: light transmission aggregometry; IA: Impedance aggregometry; PFA: Platelet Function Assay; PRP: plateletrich plasma; PPP: platelet-poor plasma.

\section{Platelet Response to Pharmacological and Non-Pharmacological Agents or Devices}

Drugs represent the most common cause of platelet dysfunction. There are several agents used in intensive care units such as antibiotics, nonsteroidal anti-inflammatory drugs and volume expanders, which can impair platelet function. Between antibiotics, the compounds that most commonly affect platelet function are $\beta$-lactam antibiotics. Some of them produce predictable dose-dependent and duration-related effects on the bleeding time. Agonist-induced platelet aggregation is reduced from 25 to $75 \%$ in patients receiving large doses of $\beta$-lactam antibiotics. Their inhibitory effect is a maximum of one to three days after administration and can persist for several days after pharmacological discontinuance, suggesting that the action of antibiotics on platelets in vivo is presumably irreversible. Many mechanisms of alteration of platelets function have been proposed. Some antibiotics impair the interaction of platelet agonists (such as ADP and epinephrine) and/or von Willebrand factor with their corresponding receptors on the platelet surface. Antibiotics can also inhibit platelet function by binding to one or more membrane components necessary for adhesive interactions with the vessel wall [82-84].

Another complication induced using antibiotics is thrombocytopenia. Drug-induced immune thrombocytopenia can occur after common antibiotics administration like ceftriaxone, trimethoprim-sulfamethoxazole, vancomycin and penicillin. Typically, it occurs within one to two weeks of exposure to the drug, with an improvement within one to two days of drug discontinuation. Although rare, drug-induced immune thrombocytopenia can be fatal [85]. 
Nevertheless, in most cases, it is difficult to prove a causal relation of bleeding events to antibiotic therapy - particularly in intensive care units, where patients receive high doses of antibiotics and have multiple risk factors for hemorrhages.

Several pharmacological agents employed for their analgesic, anti-inflammatory or antipyretic effects can also impair platelet function by interfering with arachidonic acid metabolism. In apposition to aspirin, these drugs (including diclofenac, ibuprofen, indomethacin and naproxen) do not irreversibly block COX-1, but only as long as the drug circulates. Thus, their effect on platelets function is generally short lasting $(<4 \mathrm{~h})$ [86]. An exception is piroxicam, with a more prolonged platelet inhibition due to its plasma half-life of two days [84]. The individual bleeding risk induced by aspirin or other NSAIDs is quite unforeseeable (although often mild), but it rises significantly if concomitant comorbidities (e.g., hemophilia, chronic liver disease, renal failure), co-medication (e.g., antiviral drugs, anticoagulants) or some settings (e.g., delivery) predispose to hemorrhage [82,87].

Unfractionated heparin (UFH) and low-molecular-weight heparins (LMWHs) predispose to bleeding primarily through their anticoagulant effect, but they also have the potential to impair platelet function. Thrombocytopenia after heparin administration has been classified into two types: nonimmune heparin-induced thrombocytopenia and antibody-mediated heparin-induced thrombocytopenia, the latter commonly referred to as heparin-induced thrombocytopenia (HIT) [88]. HIT is an adverse drug reaction due to pathogenic antibodies against complexes of platelet factor-4 (PF4) and heparin. These antibodies activate platelets, neutrophils and monocytes, triggering platelet function, neutrophil extracellular trap formation and thrombin generation. Patients are unlikely to develop HIT after a short exposure to heparin because the pathologic antibodies form after a median of 4 days [89]. The risk of development of heparin-induced thrombocytopenia changes depending on the type of heparin, duration of exposure and the patient population, and it occurs in $<0.1-7 \%$ of heparin-treated patients. HIT is more frequent after exposure to unfractionated heparin compared to low molecular weight heparin (LMWH). Among LMWHs, fondaparinux has a negligible risk of HIT and is increasingly used in the treatment of HIT. Treatment consists of stopping heparin administration and also switching to an alternative anticoagulant. Without treatment, the rate of thrombosis is about $6 \%$ per day $[90,91]$. Apart from that, heparins can intensify platelet responsiveness to weak stimuli such as ADP, associate directly with the platelet surface and promote platelet activation, as demonstrated by P-selectin expression and increased binding of fibrinogen or the fibrinogen-mimetic antibody PAC-1 to the platelet receptor $\alpha \mathrm{IIb} \beta 3$ [91]. Lately, it was shown that UFH promotes platelet responsiveness by potentiating $\alpha \mathrm{IIb} \beta 3$-mediated outside-in signaling. Where on the $\alpha \mathrm{IIb} \beta 3$ complex heparin specifically interacts is not known. Both abciximab and eptifibatide prevent platelet spreading on immobilized heparin suggesting that heparin may interact with $\alpha \mathrm{IIb} \beta 3$ [88].

Major surgery can cause hemostatic changes through different mechanisms related to surgical stress, tissue destruction and inflammatory reactions. These changes determine a shift of volume from the extravascular space to the intravascular compartment and interstitial space and thus hemodilution of coagulation proteins and an increased plasmatic fibrinogen concentration and platelets. These factors, combined with a hypofibrinolytic status, leads to a postoperative hypercoagulable state. Fluid infusion, in particular the administration of colloids, during surgery is associated with a prolongation of standard clotting times (CTs) and a decrease in plasma levels of coagulation factors and inhibitors of coagulation [92,93]. FVIII and von Willebrand factor (VWF) show a gradual increase during surgery-probably secondary to increases in stress hormones, including epinephrine and vasopressin-to inflammatory responses and endothelial activation. Moreover, the number of platelets increases and is not related to the degree of dilution, but presumably to the release of platelets from the spleen, lungs and bone marrow. Overall, major surgery is responsible for the perioperative prothrombotic state, with elevated levels of FVIII, fibrinogen, thrombin-thrombomodulin (TAT) complexes, VWF and hyperactive platelets. In the postoperative period, an increase of type 1 plasminogen activator inhibitor (PAI-1) 
levels also occurs [94,95]. Zhao et al. designed a study to assess the effect of bleeding speed on coagulation function during surgery. A total of 141 patients with massive bleeding undergoing pulmonary surgery were enrolled to compare the indicators of coagulation. The study showed how quick and slow bleedings have different impacts on the coagulation function, with quick bleeding causing poorer coagulation function in the short term, since changes of coagulation factors occur earlier than those of PLT in functional disorders because of surgical bleeding. Indeed, quick bleeding requires important amounts of coagulation factors in a short time to respond rapidly [96].

Blood-contacting medical devices (BCMDs) are frequently employed in device-assisted circulation to treat, replace or support diseased organs in human cardiovascular, pulmonary and renal systems. Despite BCMDs being an accepted therapy in these standard clinical practices, BCMD-related complications remain a significant challenge and are related to increased morbidity and mortality. The most common adverse events associated with BCMD-assisted circulation are thromboembolism and bleeding [97]. High shear stress caused by the contact between platelets surface and mechanical circulatory support devices has also been shown to cause impairment of platelet function. The origin of platelet dysfunction in patients undergoing mechanical circulatory support is likely multifactorial (contact with foreign surfaces, platelet activation and inflammatory and coagulative cascade activation) [98]. For example, hemorrhagic and thromboembolic complications are common during treatment with extracorporeal membrane oxygenation (ECMO), resulting in considerable morbidity and mortality. The most common complication is bleeding, occurring in $29-33 \%$ of adult ECMO patients. Thromboembolic complications are generally less common $[99,100]$. Thrombocytopenia is frequent in ECMO patients, regardless of the type of ECMO mode, and platelet count usually continues to decrease over the first $2-3$ days up to seven days after the device implantation. Despite strong evidence still lacking, possible causes for a quick decline are concomitant of a patient's primary disease, toxic drug effects and anticoagulation administration [98]. Between possible mechanisms responsible for platelet dysfunction, the contact of platelet artificial surfaces leads to platelet adhesion and activation, and high shear stress causes enhanced platelet activation, which may determinate an increased thrombotic propensity. At the same time, high shear stress can also cause the loss of platelet surface receptors important for platelet adhesion [98]. These alterations may result in impaired platelet adhesion and impaired activation, and thus in an increased risk of bleeding enhanced by the ongoing consumption of platelets. Antithrombotic therapy is necessary to maintain the patency of the ECMO circuit and to reduce thrombotic complications. Unfractionated heparin (UFH) is the most widely used anticoagulant, despite anticoagulation guidelines varying among ECMO centers. However, its use can result in a higher bleeding risk [99-101]. Reduced levels of platelets adhesion receptors for collagen and vWF (GPVI and GPIb $\alpha$ ) and activation-dependent platelet surface markers (CD62 or P-selectin and CD63) are reported, compared with healthy individuals, during ECMO treatment [102,103]. A recent prospective observational study by Siegel et al. investigated platelet dysfunction and its relation to outcome in ECMO patients, showing platelets from ECMO patients as severely dysfunctional and thus predisposing patients to bleeding complications and poor outcomes. Compared to controls, the expression of platelet surface markers, delta granule secretion and formation of PLA was reduced, especially in response to stimulation. Baseline CD63 expression was higher and activated GPIIb/IIIa expression in response to stimulation was lower in non-survivors on day one of ECMO [104]. Putative causes of platelet dysfunction in patients undergoing ECMO are resumed in Figure 2. 


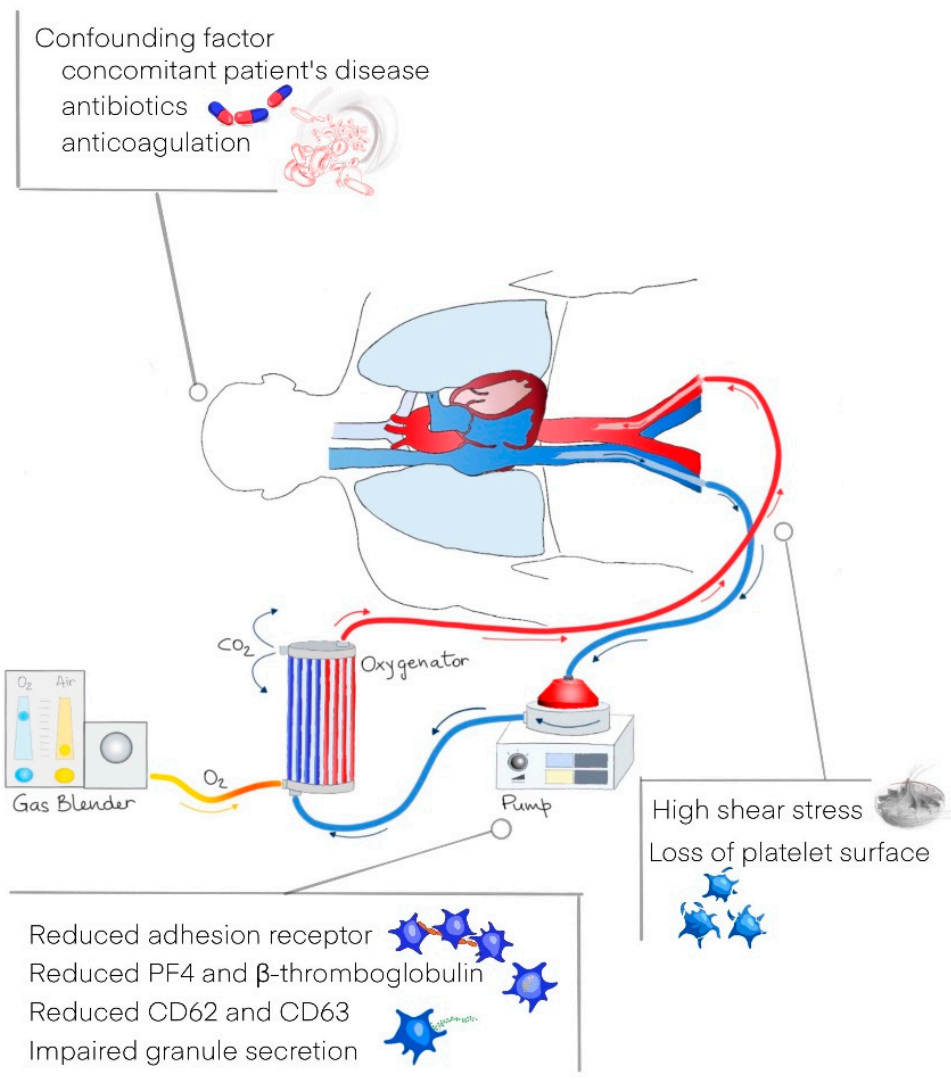

Figure 2. Proposed mechanisms for acquired platelet dysfunction during extracorporeal membrane oxygenation.

Hemostatic imbalances are an issue also in critically ill patients requiring continuous renal replacement therapy (CRRT); even in this case, the contact of foreign surfaces with blood triggers procoagulant processes. Besides worsening the prothrombotic risk related to critical illness, even uremic platelet dysfunction is characterized by a bleeding tendency. A recent analysis using multiple electrode aggregometry (MEA) revealed an impaired platelet function affecting platelet activation via arachidonic acid, adenosine diphosphate, collagen and TRAP-6-related pathways at baseline in patients at surgical intensive care units (ICU) with acute kidney injury undergoing continuous veno-venous hemodialysis (CVVHD). Test results remained below defined reference ranges despite efficient elimination of urinary excreted substances [105]. Wand et al. investigated MEA performing MultiplateR in patients with acute kidney injury before the start of CRRT and 6, 12, 24 and $48 \mathrm{~h}$ after initiation of CRRT. Aggregometric analyses showed that arachidonic acid-induced platelet aggregation was significantly reduced after $6 \mathrm{~h}$ when compared to the baseline. The results of the present study indicate that CRRT may lead to impaired primary hemostasis, as shown by a decrease in ex vivo arachidonic acid-induced platelet aggregation [106].

Finally, the interaction between vaccines and platelets has recently gained much attention. Some cases reported the occurrence of immune thrombocytopenia and thrombosis syndrome after the administration of the ChAdOx1 $\mathrm{nCoV}-19$ vaccine (AZD1222). The diagnosis of vaccine-induced immune thrombocytopenia and thrombosis (VITT) is based on specific clinical and laboratory data that should be used to distinguish by thrombosis with thrombocytopenia syndrome (TTS) [107]. The VITT disorder is associated with high-titer immunoglobulin $\mathrm{G}(\mathrm{IgG})$ class antibodies directed against the cationic platelet chemokine, platelet factor 4 (PF4) [108]. Adenovirus vaccine vectors can interact directly with and activate platelets, and these activated platelets are cleared from the circulation by Kupfer cells in the liver [109]. 
Most patients with thrombocytopenia and thrombotic events showed that increased levels of PF4 and anti-PF4 antibodies are found in patients with COVID-19 despite no history of heparin use [110]. Thus, vaccine-mediated thrombosis is due to immune complex formation. An interesting observation is that both SARS-CoV-2 infection and vaccination are both associated with thrombosis, although there are some clinical differences. Both infection and vaccination are associated with PF4-mediated thrombocytopenia. Conversely, while the infection leads to multi-organ failure, vaccination seems to lead to more focal thrombosis, typically in the brain or liver. Nowadays, the possibility of preventing and treating a rare event such as vaccine-related thrombosis remains an unresolved question.

\section{Clinical Consequences of Platelets Dysregulation}

As previously described, platelets play a pivotal role both in the regulation of coagulation and immune response in severe infection. Consequently, clinical effects of platelet dysregulation after severe infections can be categorized as (i) Thrombohemorrhagic complication (ii) reduced bacterial clearance (iii) endothelial damage and inflammation. Notably, the crosstalk between coagulation and immune response is confirmed by the fact that these different kinds of complications are usually linked [111,112]. The most described thrombohemorrhagic complication is the occurrence of sepsis-induced thrombocytopenia $[63,113,114]$. Nonetheless, even with a pseudo-normal platelet count, platelet activation can be responsible for organ failure throughout the formation of microthrombi from platelet aggregation. In a mouse model of peritonitis, the occurrence of platelet-rich thrombi in organ microvessels is correlated with organ failure [115]. The formation of platelet-rich thrombi can be enhanced by the high shear stress found in micro vessels during sepsis $[116,117]$. On the other hand, the interaction between platelets and leukocytes can be responsible for the presence of platelet-leucocyte aggregates (PLA) in the blood [118-120]. Circulating PLA is increased in sepsis patients at an early phase, but significantly, decreases in patients developing multiple organ failure [121,122]. Although causality is yet to be demonstrated, it is probably an indirect sign of peripheric sequestration of PLA in the vessel. The role of PLA in determining organ failure is reflected by the complete reversal of acid-induced acute lung injury in a murine model where platelet-neutrophil aggregation was blocked [123].

Platelet-neutrophil aggregates can also potentiate thrombocytopenia through the release of platelet-activating neutrophil extracellular trap (NETs) [124]. NETs formation is critical for the development of sepsis-induced intravascular coagulation, regardless of the inciting bacterial stimulus (gram-negative, gram-positive or bacterial products) [125-127].

The role of platelets in supporting the host defense is supported by several studies. It has been shown that thrombocytopenia impairs host defense during Streptococcus pneumoniae infection [128], in Gram negative pneumonia and sepsis [129] and amyloidosis [130]. Recently, a cause-effect relationship was described. In a landmark paper by Claushuis et al., a distinct whole-blood leukocyte transcriptome pattern revealed decreased leukocyte adhesion, diapedesis and extravasation signaling in severe thrombocytopenia [131].

In the last years, while the effect of dysregulated platelet activation has been described, its therapeutic approach is far to be elucidated. Recently, some RCTs have tried to investigate the effects of antiplatelet drugs in septic patients, with controversial results [132-136]. The complex dynamic behavior of platelets during severe infection can be partially responsible for these results. A deeper analysis of the timing of platelet activation can support targeting the antiplatelet therapy before organ failure is developed. Conversely, in patients with already acquired platelet dysfunction, a therapeutic approach aiming to minimize the risk of bleeding can be recommended, and some authors suggest a higher threshold for platelet transfusion in these patients [32]. Recent studies have suggested that platelets dysfunction may result in an "exhausted state," resulting in an increased risk of bleeding complications [99]. 


\section{Conclusions}

In conclusion, the role of platelets as a contributor to the immune system has been established. The occurrence of platelet dysfunction during severe infection is common and can be associated with a weaker host response to infections and worse outcomes. Exacerbated platelet activation in sepsis may also contribute to a dysregulation of the inflammatory and immune response in sepsis, which could favor the genesis of multi-organ failure. Assessment of platelet function during infection is gaining relevance as a clinical and research tool useful to improve our knowledge regarding disease pathogenesis and therapeutic options.

Author Contributions: A.F. conceived the review and is responsible for the final draft of the manuscript. G.C.C., M.M., G.P. and S.S. contribute to write the manuscript and made critical revision of the manuscript for key intellectual content. M.M. contributed to graphic editing. R.P. and C.A.V. made critical revision of the manuscript for key intellectual content. All authors have read and agreed to the published version of the manuscript.

Funding: This research received no external funding.

Acknowledgments: The authors would thank Dylan Ryan Mejia (University of Ferrara) who edited the manuscript for proper English language.

Conflicts of Interest: The authors declare no conflict of interest.

\section{References}

1. Clemetson, K.J.; Clemetson, J.M.; Proudfoot, A.E.; Power, C.A.; Baggiolini, M.; Wells, T.N. Functional expression of CCR1, CCR3, CCR4, and CXCR4 chemokine receptors on human platelets. Blood 2000, 96, 4046-4054. [CrossRef]

2. Youssefian, T.; Drouin, A.; Massé, J.-M.; Guichard, J.; Cramer, E.M. Host defense role of platelets: Engulfment of HIV andStaphylococcus aureus occurs in a specific subcellular compartment and is enhanced by platelet activation. Blood 2002, 99, 4021-4029. [CrossRef] [PubMed]

3. Antczak, A.J.; Singh, N.; Gay, S.R.; Worth, R.G. IgG-complex stimulated platelets: A source of sCD40L and RANTES in initiation of inflammatory cascade. Cell Immunol. 2010, 263, 129-133. [CrossRef] [PubMed]

4. Gleissner, C.A.; von Hundelshausen, P.; Ley, K. Platelet Chemokines in Vascular Disease. Arter. Thromb. Vasc. Biol. 2008, 28, 1920-1927. [CrossRef] [PubMed]

5. Yeaman, M.R. Bacterial-platelet interactions: Virulence meets host defense. Future Microbiol. 2010, 5, 471-506. [CrossRef]

6. Stark, K.; Massberg, S. Interplay between inflammation and thrombosis in cardiovascular pathology. Nat. Rev. Cardiol. 2021, 18, 666-682. [CrossRef] [PubMed]

7. Nicolai, L.; Schiefelbein, K.; Lipsky, S.; Leunig, A.; Hoffknecht, M.; Pekayvaz, K.; Raude, B.; Marx, C.; Ehrlich, A.; Pircher, J.; et al. Vascular surveillance by haptotactic blood platelets in inflammation and in-fection. Nat. Commun. 2020, 11, 5778. [CrossRef]

8. Verschoor, A.; Neuenhahn, M.; Navarini, A.A.; Graef, P.; Plaumann, A.; Seidlmeier, A.; Nieswandt, B.; Massberg, S.; Zinkernagel, R.M.; Hengartner, H.; et al. A platelet-mediated system for shuttling blood-borne bacteria to CD8 $\alpha+$ dendritic cells depends on glycoprotein GPIb and complement C3. Nat. Immunol. 2011, 12, 1194-1201. [CrossRef]

9. Lourbakos, A.; Yuan, Y.P.; Jenkins, A.L.; Travis, J.; Andrade-Gordon, P.; Santulli, R.; Potempa, J.; Pike, R.N. Activation of protease-activated receptors by gingipains from Porphyromonas gingivalis leads to platelet aggregation: A new trait in mi-crobial pathogenicity. Blood 2001, 97, 3790-3797. [CrossRef]

10. Ståhl, A.L.; Svensson, M.; Mörgelin, M.; Svanborg, C.; Tarr, P.I.; Mooney, J.C.; Watkins, S.L.; Johnson, R.; Karpman, D. Lipopolysaccharide from enterohemorrhagic Escherichia coli binds to platelets through TLR4 and CD62 and is detected on circulating platelets in patients with hemolytic uremic syndrome. Blood 2006, 108, 167-176. [CrossRef]

11. Kerrigan, S.W.; Douglas, I.; Wray, A.; Heath, J.; Byrne, M.F.; Fitzgerald, D.; Cox, D. A role for glycoprotein Ib in Streptococcus sanguis-induced platelet aggregation. Blood 2002, 100, 509-516. [CrossRef] [PubMed]

12. Miajlovic, H.; Zapotoczna, M.; Geoghegan, J.A.; Kerrigan, S.W.; Speziale, P.; Foster, T.J. Direct interaction of iron-regulated surface determinant IsdB of Staphylococcus aureus with the GPIIb/IIIa receptor on platelets. Microbiology 2010, 156, 920-928. [CrossRef] [PubMed]

13. Loughman, A.; Fitzgerald, J.R.; Brennan, M.P.; Higgins, J.; Downer, R.; Cox, D.; Foster, T.J. Roles for fibrinogen, immunoglobulin and complement in platelet activation promoted by Staphylococcus aureus clumping factor A. Mol. Microbiol. 2005, 57, 804-818. [CrossRef] [PubMed]

14. Fitzgerald, J.R.; Loughman, A.; Keane, F.; Brennan, M.; Knobel, M.; Higgins, J.; Visai, L.; Speziale, P.; Cox, D.; Foster, T.J Fibron-ectin-binding proteins of Staphylococcus aureus mediate activation of human platelets via fibrinogen and fibronectin bridges to integrin GPIIb/IIIa and IgG binding to the FcgammaRIIa receptor. Mol. Microbiol. 2006, 59, 212-230. [CrossRef] [PubMed] 
15. Dornieden, C.; Beyrich, C.; Schinke, B.; Schubert-Unkmeir, A.; Abele-Horn, M.; Speer, C.P.; Siauw, C.; Kobsar, A.; Eigenthaler, M. Group B streptococcus isolates from septic patients and healthy carriers differentially activate platelet signaling cascades. Thromb. Haemost. 2006, 95, 836-849. [CrossRef] [PubMed]

16. Kerrigan, S.W. The expanding field of platelet-bacterial interconnections. Platelets 2015, 26, 293-301. [CrossRef]

17. Kerrigan, S.W.; Cox, D. Platelet-bacterial interactions. Cell Mol. Life Sci. 2010, 67, 513-523. [CrossRef]

18. Cox, D.; Kerrigan, S.W.; Watson, S.P. Platelets and the innate immune system: Mechanisms of bacterial-induced platelet ac-tivation. J. Thromb. Haemost. 2011, 9, 1097-1107. [CrossRef]

19. Byrne, M.F.; Kerrigan, S.W.; Corcoran, P.A.; Atherton, J.C.; Murray, F.E.; Fitzgerald, D.J.; Cox, D.M. Helicobacter pylori binds von Willebrand factor and interacts with GPIb to induce platelet aggregation. Gastroenterology 2003, 124, 1846-1854. [CrossRef]

20. Kerrigan, S.W.; Jakubovics, N.; Keane, C.; Maguire, P.; Wynne, K.; Jenkinson, H.; Cox, D. Role of Streptococcus gordonii Surface Proteins SspA/SspB and Hsa in Platelet Function. Infect. Immun. 2007, 75, 5740-5747. [CrossRef]

21. Beynon, R.P.; Bahl, V.K.; Prendergast, B.D. Infective endocarditis. BMJ 2006, 333, 334-339. [CrossRef] [PubMed]

22. Claessens, Y.-E.; Dhainaut, J.-F. Diagnosis and treatment of severe sepsis. Crit. Care 2007, 11, S2. [CrossRef] [PubMed]

23. Yaguchi, A.; Lobo, F.L.M.; Vincent, J.-L.; Pradier, O. Platelet function in sepsis. J. Thromb. Haemost. 2004, 2, 2096-2102. [CrossRef] [PubMed]

24. Alt, E.; Amann-Vesti, B.R.; Madl, C.; Funk, G.; Koppensteiner, R. Platelet aggregation and blood rheology in severe sepsis/septic shock: Relation to the Sepsis-related Organ Failure Assessment (SOFA) score. Clin. Hemorheol. Microcirc. 2004, 30, 107-115. [PubMed]

25. Sharma, B.; Sharma, M.; Majumder, M.; Steier, W.; Sangal, A.; Kalawar, M. Thrombocytopenia in septic shock patients-A pro-spective observational study of incidence, risk factors and correlation with clinical outcome. Anaesth. Intensive Care 2007, 35, 874-880. [CrossRef]

26. Coppinger, J.A.; Cagney, G.; Toomey, S.; Kislinger, T.; Belton, O.; McRedmond, J.P.; Cahill, D.J.; Emili, A.; Fitzgerald, D.J.; Maguire, P.B. Characterization of the proteins released from activated platelets leads to localization of novel platelet proteins in human atherosclerotic lesions. Blood 2004, 103, 2096-2104. [CrossRef]

27. McRedmond, J.P.; Park, S.D.; Reilly, D.F.; Coppinger, J.A.; Maguire, P.B.; Shields, D.C.; Fitzgerald, D.J. Integration of proteomics and genomics in platelets: A profile of platelet proteins and platelet-specific genes. Mol. Cell Proteom. 2004, 3, 133-144. [CrossRef]

28. Gawaz, M.; Stellos, K.; Langer, H.F. Platelets modulate atherogenesis and progression of atherosclerotic plaques via interaction with progenitor and dendritic cells. J. Thromb. Haemost. 2008, 6, 235-242. [CrossRef]

29. Koyama, H.; Nishizawa, Y. Platelet in progression of atherosclerosis: A potential target in diabetic patients. Curr. Diabetes Rev. 2005, 1, 159-165. [CrossRef]

30. Langer, H.F.; Gawaz, M. Platelet-vessel wall interactions in atherosclerotic disease. Thromb. Haemost. 2008, 99, 480-486. [CrossRef]

31. May, A.E.; Seizer, P.; Gawaz, M. Platelets: Inflammatory Firebugs of Vascular Walls. Arter. Thromb. Vasc. Biol. 2008, 28, 5-10. [CrossRef] [PubMed]

32. Kuckleburg, C.J.; Tiwari, R.; Czuprynski, C.J. Endothelial cell apoptosis induced by bacteria-activated platelets requires caspase-8 and -9 and generation of reactive oxygen species. Thromb. Haemost. 2008, 99, 363-372. [CrossRef]

33. Campo, G.; Contoli, M.; Fogagnolo, A.; Sega, F.V.D.; Zucchetti, O.; Ronzoni, L.; Verri, M.; Fortini, F.; Pavasini, R.; Morandi, L.; et al Over time relationship between platelet reactivity, myocardial injury and mortality in patients with SARS-CoV-2-associated respiratory failure. Platelets 2020, 32, 560-567. [CrossRef] [PubMed]

34. Vieira-De-Abreu, A.; Campbell, R.A.; Weyrich, A.S.; Zimmerman, G.A. Platelets: Versatile effector cells in hemostasis, inflammation, and the immune continuum. Semin. Immunopathol. 2011, 34, 5-30. [CrossRef] [PubMed]

35. Middleton, E.A.; Weyrich, A.; Zimmerman, G.A. Platelets in Pulmonary Immune Responses and Inflammatory Lung Diseases. Physiol. Rev. 2016, 96, 1211-1259. [CrossRef]

36. Assinger, A. Platelets and infection-an emerging role of platelets in viral infection. Front. Immunol. 2014, 18, 649. [CrossRef]

37. Mukhopadhyay, S.; Kuhn, R.J.; Rossmann, M.G. A structural perspective of the flavivirus life cycle. Nat. Rev. Microbiol. 2005, 3, 13-22. [CrossRef]

38. Blijleven, J.S.; Boonstra, S.; Onck, P.; van der Giessen, E.; van Oijen, A.M. Mechanisms of influenza viral membrane fusion. Semin. Cell Dev. Biol. 2016, 60, 78-88. [CrossRef]

39. Dutartre, H.; Clavière, M.; Journo, C.; Mahieux, R. Cell-Free versus Cell-to-Cell Infection by Human Immunodeficiency Virus Type 1 and Human T-Lymphotropic Virus Type 1: Exploring the Link among Viral Source, Viral Trafficking, and Viral Replication. J. Virol. 2016, 90, 7607-7617. [CrossRef]

40. Guo, L.; Feng, K.; Wang, Y.C.; Mei, J.J.; Ning, R.T.; Zheng, H.W.; Wang, J.J.; Worthen, G.S.; Wang, X.; Song, J.; et al. Critical role of CXCL4 in the lung pathogenesis of influenza (H1N1) respiratory infection. Mucosal Immunol. 2017, 10, 1529-1541. [CrossRef]

41. Jenne, C.N.; Wong, C.; Zemp, F.J.; McDonald, B.; Rahman, M.M.; Forsyth, P.A.; McFadden, G.; Kubes, P. Neutrophils Recruited to Sites of Infection Protect from Virus Challenge by Releasing Neutrophil Extracellular Traps. Cell Host Microbe 2013, 13, 169-180. [CrossRef] [PubMed]

42. Loria, G.D.; Romagnoli, P.; Moseley, N.B.; Rucavado, A.; Altman, J.D. Platelets support a protective immune response to LCMV by preventing splenic necrosis. Blood 2013, 121, 940-950. [CrossRef] [PubMed]

43. Shashkin, P.N.; Brown, G.T.; Ghosh, A.; Marathe, G.; McIntyre, T.M. Lipopolysaccharide Is a Direct Agonist for Platelet RNA Splicing. J. Immunol. 2008, 181, 3495-3502. [CrossRef] [PubMed] 


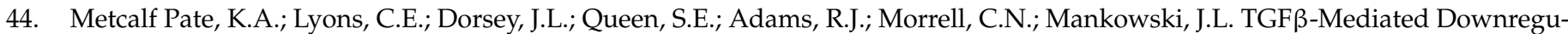
lation of Thrombopoietin Is Associated With Platelet Decline in Asymptomatic SIV Infection. J. Acquir. Immune. Defic Syndr. 2014, 65, 510-516. [CrossRef] [PubMed]

45. Isomura, H.; Yoshida, M.; Oda, M.; Seino, Y.; Ohuchi, R.; Uno, F.; Yamada, M.; Namba, H.; Fujiwara, N. Suppressive effects of human herpesvirus-6 on thrombopoietin-inducible megakaryocytic colony formation in vitro. J. Gen. Virol. 2000, 81, 663-673. [CrossRef] [PubMed]

46. Gonelli, A.; Mirandola, P.; Grill, V.; Secchiero, P.; Zauli, G. Human herpesvirus 7 infection impairs the survival/differentiation of megakaryocytic cells. Haematologica 2002, 87, 1223-1225. [PubMed]

47. Afdhal, N.; McHutchison, J.; Brown, R.; Jacobson, I.; Manns, M.; Poordad, F.; Weksler, B.; Esteban, R. Thrombocytopenia associated with chronic liver disease. J. Hepatol. 2008, 48, 1000-1007. [CrossRef]

48. Chelucci, C.; Federico, M.; Guerriero, R.; Mattia, G.; Casella, I.; Pelosi, E.; Testa, U.; Mariani, G.; Hassan, H.J.; Peschle, C. Productive human immunodeficiency virus-1 infection of purified megakaryocytic progenitors/precursors and maturing megakar-yocytes. Blood 1998, 91, 1225-1234. [CrossRef]

49. Li, X.; Jeffers, L.J.; Garon, C.; Fischer, E.R.; Scheffel, J.; Moore, B.; Reddy, K.R.; Demedina, M.; Schiff, E.R. Persistence of hepatitis C virus in a human megakaryoblastic leukaemia cell line. J. Viral Hepat. 1999, 6, 107-114. [CrossRef]

50. Crapnell, K.; Zanjani, E.D.; Chaudhuri, A.; Ascensao, J.L.; Jeor, S.S.; Maciejewski, J.P. In vitro infection of megakaryocytes and their precursors by human cytomegalovirus. Blood 2000, 95, 487-493. [CrossRef]

51. Flaujac, C.; Boukour, S.; Cramer-Bordé, E. Platelets and viruses: An ambivalent relationship. Cell. Mol. Life Sci. 2009, 67, 545-556. [CrossRef] [PubMed]

52. Assinger, A.; Kral, J.B.; Yaiw, K.-C.; Schrottmaier, W.C.; Kurzejamska, E.; Wang, Y.; Mohammad, A.-A.; Religa, P.; Rahbar, A.; Schabbauer, G.; et al. Human Cytomegalovirus-Platelet Interaction Triggers Toll-Like Receptor 2-Dependent Proinflammatory and Proangiogenic Responses. Arter. Thromb. Vasc. Biol. 2014, 34, 801-809. [CrossRef] [PubMed]

53. Coulson, B.; Londrigan, S.; Lee, D.J. Rotavirus contains integrin ligand sequences and a disintegrin-like domain that are implicated in virus entry into cells. Proc. Natl. Acad. Sci. USA 1997, 94, 5389-5394. [CrossRef]

54. Mackow, E.R.; Gavrilovskaya, I.N. Cellular Receptors and Hantavirus Pathogenesis. In Hantaviruses. Current Topics in Microbiology and Immunology; Schmaljohn, C.S., Nichol, S.T., Eds.; Springer: Berlin/Heidelberg, Germany, 2001; pp. 91-115.

55. Nunez, D.; Charriaut-Marlangue, C.; Barel, M.; Benveniste, J.; Frade, R. Activation of human platelets through gp140, the C3d/EBV receptor (CR2). Eur. J. Immunol. 1987, 17, 515-520. [CrossRef] [PubMed]

56. Chaipan, C.; Soilleux, E.J.; Simpson, P.; Hofmann, H.; Gramberg, T.; Marzi, A.; Geier, M.; Stewart, E.A.; Eisemann, J.; Steinkasserer, A.; et al. DC-SIGN and CLEC-2 Mediate Human Immunodeficiency Virus Type 1 Capture by Platelets. J. Virol. 2006, 80, 8951-8960. [CrossRef] [PubMed]

57. Maugeri, N.; Cattaneo, M.; Rovere-Querini, P.; Manfredi, A.A. Platelet clearance by circulating leukocytes: A rare event or a de-terminant of the "immune continuum"? Platelets 2014, 25, 224-225. [CrossRef] [PubMed]

58. Grozovsky, R.; Hoffmeister, K.M.; Falet, H. Novel clearance mechanisms of platelets. Curr. Opin. Hematol. 2010, 17, 585-589. [CrossRef] [PubMed]

59. Yeaman, M.R. Platelets in defense against bacterial pathogens. Cell. Mol. Life Sci. 2009, 67, 525-544. [CrossRef]

60. Goeijenbier, M.; van Wissen, M.; van de Weg, C.; Jong, E.; Gerdes, V.; Meijers, J.; Brandjes, D.; van Gorp, E. Review: Viral infections and mechanisms of thrombosis and bleeding. J. Med. Virol. 2012, 84, 1680-1696. [CrossRef]

61. Palmer, L.; Briggs, C.; McFadden, S.; Zini, G.; Burthem, J.; Rozenberg, G.; Proytcheva, M.; Machin, S.J. ICSH recommendations for the standardization of nomenclature and grading of peripheral blood cell morphological features. Int. J. Lab. Hematol. 2015, 37, 287-303. [CrossRef]

62. Fogagnolo, A.; Taccone, F.S.; Campo, G.; Montanari, G.; Capatti, B.; Ferraro, G.; Erriquez, A.; Ragazzi, R.; Creteur, J.; Volta, C.A.; et al. Impaired platelet reactivity in patients with septic shock: A proof-of-concept study. Platelets 2019, 31, 652-660. [CrossRef] [PubMed]

63. Drews, R.E.; Weinberger, S.E. Thrombocytopenic Disorders in Critically Ill Patients. Am. J. Respir. Crit. Care Med. 2000, 162, 347-351. [CrossRef] [PubMed]

64. Singer, M.; Deutschman, C.S.; Seymour, C.W.; Shankar-Hari, M.; Annane, D.; Bauer, M.; Bellomo, R.; Bernard, G.R.; Chiche, J.-D.; Coopersmith, C.M.; et al. The Third International Consensus Definitions for Sepsis and Septic Shock (Sepsis-3). JAMA 2016, 315, 801-810. [CrossRef] [PubMed]

65. Jagroop, I.A.; Clatworthy, I.; Lewin, J.; Mikhailidis, D.P. Shape change in human platelets: Measurement with a channelyzer and visualisation by electron microscopy. Platelets 2000, 11, 28-32.

66. Zampieri, F.G.; Ranzani, O.T.; Sabatoski, V.; De Souza, H.P.; Barbeiro, H.; Da Neto, L.M.C.; Park, M.; Da Silva, F.P. An increase in mean platelet volume after admission is associated with higher mortality in critically ill patients. Ann. Intensive Care 2014, 4, 20. [CrossRef] [PubMed]

67. Tajarernmuang, P.; Phrommintikul, A.; Limsukon, A.; Pothirat, C.; Chittawatanarat, K. The Role of Mean Platelet Volume as a Predictor of Mortality in Critically Ill Patients: A Systematic Review and Meta-Analysis. Crit. Care Res. Pr. 2016, 2016, 4370834. [CrossRef] 
68. Fogagnolo, A.; Taccone, F.S.; Benetto, G.; Franchi, F.; Scolletta, S.; Cotoia, A.; Kozhevnikova, I.; Volta, C.A.; Spadaro, S. Platelet mor-phological indices on Intensive Care Unit admission predict mortality in septic but not in non-septic patients. Minerva Anestesiol. 2021, 87, 184-192. [CrossRef]

69. Yilmaz, Z.; Eralp, O.; Ilcol, Y.O. Evaluation of platelet count and its association with plateletcrit, mean platelet volume, and platelet size distribution width in a canine model of endotoxemia. Veter. Clin. Pathol. 2008, 37, 159-163. [CrossRef]

70. Cotoia, A.; Franchi, F.; De Fazio, C.; Vincent, J.-L.; Creteur, J.; Taccone, F.S. Platelet indices and outcome after cardiac arrest. BMC Emerg. Med. 2018, 18, 31. [CrossRef]

71. Furie, B.; Furie, B.C. Role of platelet P-selectin and microparticle PSGL-1 in thrombus formation. Trends Mol. Med. 2004, 10, 171-178. [CrossRef]

72. Zhou, J.; Xu, E.; Shao, K.; Shen, W.; Gu, Y.; Li, M.; Shen, W. Circulating platelet-neutrophil aggregates as risk factor for deep venous thrombosis. Clin. Chem. Lab. Med. 2018, 57, 707-715. [CrossRef] [PubMed]

73. Schrijver, I.T.; Kemperman, H.; Roest, M.; Kesecioglu, J.; De Lange, D. Soluble P-selectin as a Biomarker for Infection and Survival in Patients With a Systemic Inflammatory Response Syndrome on the Intensive Care Unit. Biomark. Insights 2017, 12. [CrossRef] [PubMed]

74. Spadaro, S.; Fogagnolo, A.; Campo, G.; Zucchetti, O.; Verri, M.; Ottaviani, I.; Tunstall, T.; Grasso, S.; Scaramuzzo, V.; Murgolo, F.; et al. Markers of endothelial and epithelial pulmonary injury in mechanically ventilated COVID-19 ICU patients. Crit. Care 2021, 25, 74. [CrossRef] [PubMed]

75. de Stoppelaar, S.F.; Van't Veer, C.; Roelofs, J.J.; Claushuis, T.A.; de Boer, O.J.; Tanck, M.W.; Hoogendijk, A.J.; van der Poll, T. Platelet and endothelial cell P-selectin are required for host defense against Klebsiella pneumoniae-induced pneumosepsis. $J$. Thromb Haemost. 2015, 13, 1128-1238. [CrossRef]

76. Femia, E.A.; Scavone, M.; Lecchi, A.; Cattaneo, M. Effect of platelet count on platelet aggregation measured with impedance aggregometry (Multiplate ${ }^{\mathrm{TM}}$ analyzer) and with light transmission aggregometry. J. Thromb. Haemost. 2013, 11, $2193-2196$. [CrossRef]

77. Le Blanc, J.; Lordkipanidzé, M. Platelet Function in Aging. Front. Cardiovasc. Med. 2019, 6, 109. [CrossRef]

78. Cattaneo, M.; Cerletti, C.; Harrison, P.; Hayward, C.; Kenny, D.; Nugent, D.; Nurden, P.; Rao, A.K.; Schmaier, A.H.; Watson, S.; et al. Recommendations for the standardization of light transmission aggregometry: A consensus of the working party from the platelet physiology subcommittee of SSC/ISTH. J. Thromb. Haemost. 2013, 11, 1183-1189. [CrossRef]

79. Seyfert, U.T.; Haubelt, H.; Vogt, A.; Hellstern, P. Variables influencing Multiplate(TM) whole blood impedance platelet aggregometry and turbidimetric platelet aggregation in healthy individuals. Platelets 2007, 18, 199-206. [CrossRef]

80. Spurgeon, B.E.; Naseem, K.M. Platelet Flow Cytometry: Instrument Setup, Controls, and Panel Performance. Cytom. Part. B: Clin. Cytom. 2019, 98, 19-27. [CrossRef]

81. Spurgeon, B.E.J.; Michelson, A.D.; Iii, A.L.F. Platelet mass cytometry: Optimization of sample, reagent, and analysis parameters Cytom. A 2021, 99, 170-179. [CrossRef]

82. Scharf, R.E. Drugs that Affect Platelet Function. Semin. Thromb. Hemost. 2012, 38, 865-883. [CrossRef] [PubMed]

83. Burroughs, S.F.; Johnson, G.J. Beta-lactamantibiotic-induced platelet dysfunction: Evidence for irreversible inhibition of platelet activation in vitro and in vivo after prolonged exposure to penicillin. Blood 1990, 75, 1473-1480. [CrossRef] [PubMed]

84. Shattil, S.J.; Bennett, J.S.; McDonough, M.; Turnbull, J. Carbenicillin and penicillin G inhibit platelet function in vitro by im-pairing the interaction of agonists with the platelet surface. J. Clin. Investig. 1980, 65, 329-337. [CrossRef] [PubMed]

85. Kiliaki, S. Piperacillin-Tazobactam-Induced Immune Thrombocytopenia: A Case Report. J. Pharm. Pr. 2021, 08971900211048140 [CrossRef] [PubMed]

86. Warner, T.D.; Nylander, S.; Whatling, C. Anti-platelet therapy: Cyclo-oxygenase inhibition and the use of aspirin with par-ticular regard to dual anti-platelet therapy. Br. J. Clin. Pharmacol. 2011, 72, 619-633. [CrossRef] [PubMed]

87. Schafer, A.I. Effects of Nonsteroidal Antiinflammatory Drugs on Platelet Function and Systemic Hemostasis. J. Clin. Pharmacol. 1995, 35, 209-219. [CrossRef]

88. Gao, C.; Boylan, B.; Fang, J.; Wilcox, D.A.; Newman, D.K.; Newman, P.J. Heparin promotes platelet responsiveness by potentiating $\alpha \mathrm{IIb} \beta 3$-mediated outside-in signaling. Blood 2011, 117, 4946-4952. [CrossRef]

89. Arepally, G.M. Heparin-induced thrombocytopenia. Blood 2017, 129, 2864-2872. [CrossRef]

90. Cuker, A.; Arepally, G.M.; Chong, B.H.; Cines, D.B.; Greinacher, A.; Gruel, Y.; Linkins, L.A.; Rodner, S.B.; Selleng, S.; Warkentin, T.E.; et al. American Society of Hematology 2018 guidelines for management of venous thromboembolism: Heparin-induced thrombocytopenia. Blood Adv. 2018, 2, 3360-3392. [CrossRef]

91. Greinacher, A.; Eichler, P.; Lubenow, N.; Kwasny, H.; Luz, M. Heparin-induced thrombocytopenia with thromboembolic complications: Meta-analysis of 2 prospective trials to assess the value of parenteral treatment with lepirudin and its therapeutic aPTT range. Blood 2000, 96, 846-851. [CrossRef]

92. Kozek-Langenecker, S.A.; Afshari, A.; Albaladejo, P.; Santullano, C.A.; De Robertis, E.; Filipescu, D.C.; Fries, D.; Görlinger, K.; Haas, T.; Imberger, G.; et al. Management of severe perioperative bleeding: Guidelines from the European Society of Anaesthesiology. Eur. J. Anaesthesiol. 2013, 30, 270-382. [CrossRef] [PubMed]

93. Fogagnolo, A.; Taccone, F.S.; Vincent, J.L.; Benetto, G.; Cavalcante, E.; Marangoni, E.; Ragazzi, R.; Creteur, J.; Volta, C.A.; Spadaro, S. Using arterial-venous oxygen difference to guide red blood cell transfusion strategy. Crit. Care 2020, 24, 160. [CrossRef] [PubMed] 
94. Mossberg, K.E.; Pournaras, D.J.; Welbourn, R.; le Roux, C.W.; Brogren, H. Differential response of plasma plasminogen activator inhibitor 1 after weight loss surgery in patients with or without type 2 diabetes. Surg. Obes. Relat. Dis. 2016, 13, 53-57. [CrossRef] [PubMed]

95. Aoki, K.; Nishino, N.; Baba, S.; Urano, T.; Takada, A. Postoperative changes in plasma tissue-type plasminogen activator and type I plasminogen activator inhibitor. Surg. Today 1994, 24, 1039-1043. [CrossRef]

96. Zhao, J.; Yang, D.; Zheng, D. Coagulation is more affected by quick than slow bleeding in patients with massive blood loss. Blood Coagul. Fibrinolysis 2017, 28, 121-125. [CrossRef]

97. Chen, J.; Losos, M.; Yang, S.; Li, J.; Wu, H.; Cataland, S. Increased complement activation during platelet storage. Transfusion 2017, 57, 2182-2188. [CrossRef]

98. Jiritano, F.; Serraino, G.F.; Cate, H.T.; Fina, D.; Matteucci, M.; Mastroroberto, P.; Lorusso, R. Platelets and extra-corporeal membrane oxygenation in adult patients: A systematic review and meta-analysis. Intensiv. Care Med. 2020, 46, 1154-1169. [CrossRef]

99. Balle, C.M.; Jeppesen, A.N.; Christensen, S.; Hvas, A.-M. Platelet Function During Extracorporeal Membrane Oxygenation in Adult Patients: A Systematic Review. Front. Cardiovasc. Med. 2018, 5, 157. [CrossRef]

100. Vaquer, S.; De Haro, C.; Peruga, P.; Oliva, J.C.; Artigas, A. Systematic review and meta-analysis of complications and mortality of veno-venous extracorporeal membrane oxygenation for refractory acute respiratory distress syndrome. Ann. Intensive Care 2017, 7, 51. [CrossRef]

101. Chlebowski, M.M.; Baltagi, S.; Carlson, M.; Levy, J.H.; Spinella, P.C. Clinical controversies in anticoagulation monitoring and antithrombin supplementation for ECMO. Crit. Care 2020, 24, 19. [CrossRef]

102. Lukito, P.; Wong, A.; Jing, J.; Arthur, J.F.; Marasco, S.F.; Murphy, D.A.; Bergin, P.J.; Shaw, J.A.; Collecutt, M.; Andrews, R.K.; et al Mechanical circulatory support is associated with loss of platelet receptors glycoprotein Ib $\alpha$ and glycoprotein VI. J. Thromb. Haemost. 2016, 14, 2253-2260. [CrossRef] [PubMed]

103. Kalbhenn, J.; Schlagenhauf, A.; Rosenfelder, S.; Schmutz, A.; Zieger, B. Acquired von Willebrand syndrome and impaired platelet function during venovenous extracorporeal membrane oxygenation: Rapid onset and fast recovery. J. Hear. Lung Transplant. 2018, 37, 985-991. [CrossRef] [PubMed]

104. Siegel, P.M.; Chalupsky, J.; Olivier, C.B.; Bojti, I.; Pooth, J.-S.; Trummer, G.; Bode, C.; Diehl, P. Early platelet dysfunction in patients receiving extracorporeal membrane oxygenation is associated with mortality. J. Thromb. Thrombolysis 2021, 1-10. [CrossRef] [PubMed]

105. Wiegele, M.; Infanger, L.; Lacom, C.; Koch, S.; Baierl, A.; Schaden, E. Thrombin Generation and Platelet Function in ICU Patients Undergoing CVVHD Using Regional Citrate Anticoagulation. Front. Med. 2021, 8, 866. [CrossRef] [PubMed]

106. Wand, S.; Schneider, S.; Meybohm, P.; Zacharowski, K.; Weber, C.F. Assessment of hemo-static changes after initiation of con-tinuous venovenous hemodialysis. Clin. Lab. 2015, 61, 379-387. [CrossRef]

107. Guidance from the Expert Haematology Panel (EHP) on Covid-19 Vaccineinduced Immune Thrombocytopenia and Thrombosis (VITT). Available online: https://b-s-h.org.uk/about-us/news/guidance-produced-by-the-expert-haematology-panel-ehpfocussed-on-vaccine-induced-thrombosis-and-thrombocytopenia-vitt/ (accessed on 5 December 2021).

108. Greinacher, A.; Thiele, T.; Warkentin, T.E.; Weisser, K.; Kyrle, P.A.; Eichinger, S. Thrombotic Thrombocytopenia after ChAdOx1 nCov-19 Vaccination. N. Engl. J. Med. 2021, 384, 2092-2101. [CrossRef]

109. Stone, D.; Liu, Y.; Shayakhmetov, D.; Li, Z.-Y.; Ni, S.; Lieber, A. Adenovirus-Platelet Interaction in Blood Causes Virus Sequestration to the Reticuloendothelial System of the Liver. J. Virol. 2007, 81, 4866-4871. [CrossRef]

110. Cai, Z.; Greene, M.I.; Zhu, Z.; Zhang, H. Structural Features and PF4 Functions that Occur in Heparin-Induced Thrombocy-topenia (HIT) Complicated by COVID- 19. Antibodies 2020, 9, 52. [CrossRef]

111. Semple, J.W. Platelets play a direct role in sepsis-associated endothelial cell death. Thromb. Haemost. 2008, 99, 249. [CrossRef]

112. Semple, J.W.; Italiano, J.E., Jr.; Freedman, J. Platelets and the immune continuum. Nat. Rev. Immunol. 2011, 11, 264-274. [CrossRef]

113. Dewitte, A.; Lepreux, S.; Villeneuve, J.; Rigothier, C.; Combe, C.; Ouattara, A.; Ripoche, J.; Dewitte, A.; Lepreux, S.; Villeneuve, J.; et al. Blood platelets and sepsis pathophysiology: A new therapeutic prospect in critical ill patients? Ann. Intensive Care 2017, 7, 115. [CrossRef] [PubMed]

114. Venkata, C.; Kashyap, R.; Farmer, J.C.; Afessa, B. Thrombocytopenia in adult patients with sepsis: Incidence, risk factors, and its association with clinical outcome. J. Intensive Care 2013, 1, 9. [CrossRef] [PubMed]

115. Bounes, V.F.; Mémier, V.; Marcaud, M.; Jacquemin, A.; Hamzeh-Cognasse, H.; Garcia, C.; Series, J.; Sié, P.; Minville, V.; Gratacap, M.P.; et al. Platelet activation and prothrombotic properties in a mouse model of peritoneal sepsis. Sci. Rep. 2018, 8 , 13536. [CrossRef] [PubMed]

116. Rana, A.; Rana, A.; Westein, E.; Westein, E.; Niego, B.; Niego, B.; Hagemeyer, C.E.; Hagemeyer, C.E.; Rana, A.; Rana, A.; et al. Shear-Dependent Platelet Aggregation: Mechanisms and Therapeutic Opportunities. Front. Cardiovasc. Med. $2019,6,141$. [CrossRef]

117. Sakariassen, K.S.; Orning, L.; Turitto, V.T. The impact of blood shear rate on arterial thrombus formation. Futur. Sci. OA 2015, 1, FSO30. [CrossRef]

118. Finsterbusch, M.; Schrottmaier, W.C.; Kral-Pointner, J.B.; Salzmann, M.; Assingerm, A. Measuring and interpreting plateletleukocyte aggregates. Platelets 2018, 29,677-685. [CrossRef] 
119. Jensen, M.K.; Brown, P.D.N.; Lund, B.V.; Nielsen, O.J.; Hasselbalch, H. Increased circulating platelet-leukocyte aggregates in myeloproliferative disorders is correlated to previous thrombosis, platelet activation and platelet count. Eur. J. Haematol. 2001, 66, 143-151. [CrossRef]

120. Liu, C.; Yang, Y.; Du, L.; Chen, S.; Zhang, J.; Zhang, C.; Zhou, J. Platelet-leukocyte aggregate is associated with adverse events after surgical intervention for rheumatic heart disease. Sci. Rep. 2019, 9, 13069. [CrossRef]

121. Gawaz, M.; Fateh-Moghadam, S.; Pilz, G.; Gurland, H.J.; Werdan, K. Platelet activation and interaction with leucocytes in pa-tients with sepsis or multiple organ failure. Eur. J. Clin. Investig. 1995, 25, 843-851. [CrossRef]

122. Hurley, S.M.; Lutay, N.; Holmqvist, B.; Shannon, O. The Dynamics of Platelet Activation during the Progression of Strepto-coccal Sepsis. PLoS ONE 2016, 11, e0163531. [CrossRef]

123. Zarbock, A.; Singbartl, K.; Ley, K. Complete reversal of acid-induced acute lung injury by blocking of platelet-neutrophil aggregation. J. Clin. Investig. 2006, 116, 3211-3219. [CrossRef] [PubMed]

124. Lupu, F.; Kinasewitz, G.; Dormer, K. The role of endothelial shear stress on haemodynamics, inflammation, coagulation and glycocalyx during sepsis. J. Cell. Mol. Med. 2020, 24, 12258-12271. [CrossRef] [PubMed]

125. Ehamzeh-Cognasse, H.; Edamien, P.; Echabert, A.; Pozzetto, B.; Ecognasse, F.; Egarraud, O. Platelets and Infections â $€^{\prime \prime}$ Complex Interactions with Bacteria. Front. Immunol. 2015, 6, 82. [CrossRef]

126. Greco, E.; Lupia, E.; Bosco, O.; Vizio, B.; Montrucchio, G. Platelets and Multi-Organ Failure in Sepsis. Int. J. Mol. Sci. 2017, 18, 2200. [CrossRef]

127. McDonald, B.; Davis, R.P.; Kim, S.-J.; Tse, M.; Esmon, C.T.; Kolaczkowska, E.; Jenne, C.N. Platelets and neutrophil extracellular traps collaborate to promote intravascular coagulation during sepsis in mice. Blood 2017, 129, 1357-1367. [CrossRef]

128. van den Boogaard, F.E.; Schouten, M.; de Stoppelaar, S.F.; Roelofs, J.J.; Brands, X.; Schultz, M.J.; van't Veer, C.; van der Poll, T. Throm-bocytopenia impairs host defense during murine Streptococcus pneumoniae pneumonia. Crit Care Med. 2015, 43, e75-e83. [CrossRef]

129. de Stoppelaar, S.F.; van 't Veer, C.; Claushuis, T.A.; Albersen, B.J.; Roelofs, J.J.; van der Poll, T. Thrombocytopenia impairs host defense in gram-negative pneumonia-derived sepsis in mice. Blood 2014, 124, 3781-3790. [CrossRef]

130. Birnie, E.; Claushuis, T.A.M.; Koh, G.C.K.W.; Limmathurotsakul, D.; Day, N.P.J.; Roelofs, J.J.T.H.; Ware, J.; Hou, B.; de Vos, A.F.; van der Poll, T.; et al. Thrombocytopenia Impairs Host Defense Against Burkholderia pseudomallei (Meli-oidosis). J. Infect. Dis. 2019, 219, 648-659. [CrossRef]

131. Claushuis, T.A.M.; Van Vught, L.A.; Scicluna, B.; Wiewel, M.A.; Klouwenberg, P.M.C.K.; Hoogendijk, A.J.; Ong, D.; Cremer, O.; Horn, J.; Franitza, M.; et al. Thrombocytopenia is associated with a dysregulated host response in critically ill sepsis patients. Blood 2016, 127, 3062-3072. [CrossRef]

132. Kor, D.J.; Erlich, J.; Gong, M.N.; Malinchoc, M.; Carter, R.E.; Gajic, O.; Talmor, D.S. Association of prehospitalization aspirin therapy and acute lung injury: Results of a multicenter international observational study of at-risk patients. Crit. Care Med. 2011, 39, 2393-2400. [CrossRef]

133. Valerio-Rojas, J.C.; Jaffer, I.J.; Kor, D.J.; Gajic, O.; Cartin-Ceba, R. Outcomes of Severe Sepsis and Septic Shock Patients on Chronic Antiplatelet Treatment: A Historical Cohort Study. Crit. Care Res. Pr. 2013, 2013, 782573. [CrossRef] [PubMed]

134. Gross, A.K.; Dunn, S.P.; Feola, D.J.; Martin, C.A.; Charnigo, R.; Li, Z.; Abdel-Latif, A.; Smyth, S.S. Clopidogrel treatment and the in-cidence and severity of community acquired pneumonia in a cohort study and meta-analysis of antiplatelet therapy in pneumonia and critical illness. J. Thromb. Thrombolysis 2013, 35, 147-154. [CrossRef] [PubMed]

135. Kor, D.J.; Carter, R.E.; Park, P.K.; Festic, E.; Banner-Goodspeed, V.M.; Hinds, R.; Talmor, D.; Gajic, O.; Ware, L.B.; Gong, M.N.; et al. Effect of Aspirin on Development of ARDS in At-Risk Patients Presenting to the Emergency Department: The LIPS-A Randomized Clinical Trial. JAMA 2016, 315, 2406-2414. [CrossRef] [PubMed]

136. Eisen, D.P.; Leder, K.; Woods, R.L.; Lockery, J.E.; McGuinness, S.L.; Wolfe, R.; Pilcher, D.; Moore, E.M.; Shastry, A.; Nelson, M.R.; et al. Effect of aspirin on deaths associated with sepsis in healthy older people (ANTISEPSIS): A ran-domised, double-blind, placebo-controlled primary prevention trial. Lancet Respir Med. 2021, 9, 186-195. [CrossRef] 